\title{
Tarihsel Süreç İçerisinde Enformasyon Dengesizliği, Uluslararası Girişimler ve Çözüm Önerileri
}

\author{
Ahmet Öztekin (Dr. Öğr. Üyesi) \\ iD Erciyes Üniversitesi Illetişim Fakültesi \\ aoztekin@outlook.com \\ Pınar Ayhan (Doktora Öğrencisi) \\ Anadolu Üniversitesi Sosyal Bilimler Enstitüsü \\ pinarayhan@outlook.com \\ Başvuru Tarihi: 17.03 .2021 \\ Yayına Kabul Tarihi: 24.04.2021 \\ Yayınlanma Tarihi: 30.07.2021 \\ https://doi.org/10.17680/erciyesiletisim.898603 \\ Öz
}

Enformasyon dengesizliğini, uluslararası girişimler çerçevesinde incelemeyi amaçlayan bu çalışma hem sorunun çözümü için gerçekleștirilen uluslararası girişimleri bütüncül bir yapıda değerlendirmeyi hem de son girişimden bu yana geçen 16 yıllık süre zarfında sorunun çözümü noktasındaki gelişmeleri ele alarak bazı çözüm önerilerinde bulunmayı hedeflemektedir.

Çalışma, enformasyon akışındaki dengesizliği çözme amacıyla başlatılan uluslararası girişimler başarılı mıdır? Ve sorun neden kapitalist bir bakış açısıyla, ülkeler/uluslar düzeyinden, çok uluslu şirketler düzeyine taşınmıştır soruları üzerine inşa edilmiştir. Enformasyonun dengesiz akışı bağlamında Birleşmiş Milletler'in (BM) söz konusu probleme yaklaşımını ve sorunun çözümü çerçevesinde oluşturulan mekanizmaları anlamak ve açıklamak üzere hazırlanan bu çalışmanın kapsamını, enformasyon dengesizliğinden ziyade, bu dengesizliği ortadan kaldırmak için gerçekleştirilen uluslararası girişimler oluşturmaktadır. $\mathrm{Bu}$ bağlamda gerçekleştirilen uluslararası girișimler çalıșmanın sınırlılığı olarak belirlenmiștir. Yukarıda belirtilen girișimlerin daha iyi anlaşılması ve süreçlerin daha net bir şekilde ortaya konulabilmesi için nitel betimsel analiz, çalışmanın yöntemi olarak benimsenmiştir.

Çalışmanın sonucunda, dengesizliğin ülkeler/uluslar düzeyinden, çok uluslu şirketler düzeyine taşındığı tespit edilmiş ve dengesiz akışın halen devam ettiği yönündeki bulgulara ulaşılmıştır. Söz konusu bulgular ışığında sorunun çözümü için somut bazı çözüm önerilerine yer verilmiştir.

Anahtar Kelimeler: Uluslararası İletişim, Enformasyon Dengesizliği, NIEO, NWICO, MacBride Raporu, WSIS. 


\title{
Information Imbalance in The Historical Process, International Initiatives and Solution Proposals
}

\author{
Ahmet Öztekin (Asst. Prof. Dr.) \\ Erciyes University Faculty of Communication \\ aoztekin@outlook.com \\ Pınar Ayhan (Ph.D. Student) \\ Anadolu University Institute of Social Sciences \\ pinarayhan@outlook.com
}

Date Received: 17.03 .2021

Date Accepted: 24.04.2021

Date Published: 30.07.2021

https://doi.org/10.17680/erciyesiletisim.898603

\begin{abstract}
This study aims to address the imbalance within the framework of international initiatives by providing information, both in the processes of international initiatives discussed the problem with a holistic structure for the last 16 years since the last attempt to handle the developments in solution the problem by taking the point seeks to offer some suggestions.

The above-mentioned international initiatives on information imbalance have been discussed in this study. The study, are international initiatives aimed at resolving the imbalance in information flow successful? And with the capitalist perspective, why the problems moved from countries/nations level to multinational companies level has been built on questions. The scope of this study, which was prepared to understand and explain the international community's approach to the problem in question and the mechanisms created within the framework of solving the problem, is the efforts to eliminate this imbalance rather than the information imbalance in the context of the unbalanced flow of information. The international initiatives undertaken in this context are the study's limitation. The study method has been qualitative descriptive analysis in order to better understand the aforementioned initiatives and to explain the processes more clearly.
\end{abstract}

As a result of the study, it was determined that the imbalance was transferred from the countries/nations level to the level of multinational companies and it was found that the unbalanced flow is still occuring. In light of these results, several concrete solution ideas to solve the problem have been included.

Keywords: International Communication, Information Imbalance, NIEO, NWICO, MacBride Report, WSIS. 


\section{Giriş}

İnsanlık tarihinin önemli bir sıçrama noktası olan dijital devrim, tüm dünyayı etkileyerek, sonuçlarıyla bilimsel ve toplumsal ilerlemede önemli bir rol oynamıștır. Çağın öznesi durumundaki enformasyon, günümüzün tartışmasız en büyük gücü olarak, tüm ülkelerin/ulusların sahip olmak için çaba harcadığı yegâne amaç haline gelmiştir. Dijital devrimle birlikte enformasyon, akışkan bir forma dönüşmüş ve daha önce hiç görülmediği kadar yoğun bir şekilde, sınır tanımadan küresel çaptaki bir akışı başlatmıştır. Ancak bu akış hem belirli noktalarda yoğunlaşarak tüm dünyanın, insanlığın ortak kaynağı olmaktan uzaklaşmış ve sadece belirli merkezleri besleyen bir yapıya dönüşmüş hem de söz konusu enformasyon, pek çok farklı noktada gelişmiş ülkelerin propaganda aracı olarak kullanılmıștır.

İletişim, enformasyon akışıyla ilişkili bir kavram olarak, çok sayıda anlamı kapsayıcı bir şekilde, üçüncü bin yıla giren insanlığın simgesi durumuna gelmiştir. Dijital devrimle birlikte gelişen teknolojilerin aşırı bolluğu ve bu alandaki uygulamaların profesyonelleşmesi, yeni bin yılda bu çok sesliliğe yeni sesler de katmaktadır (Mattelart \& Mattelart, 2016, s. 7). Teknolojilerdeki bu aşırı bolluk ve sürekli gelişme paralelinde küreselleşmenin hızı da artmakta ve iletişim, küresel çapta bir gelişme göstererek uluslararası bir karakter kazanmaktadır. Küreselleşme ve iletişim teknolojilerinin gelişimiyle birlikte dünya tek bir mekân olup, tek bir zaman içinde dönmeye başlamış ve kültürel, toplumsal, siyasal birleşmelerin görüldüğü bir alan haline gelmiștir. Elektronik iletişim araçlarının egemen kültürü yaygınlaştırarak dünyayı tek bir mekâna dönüștüreceğini öne süren McLuhan, bu durumu "Küresel Köy" tanımlamasıyla kavramsallaştırmıştır (Altay, 2005, s. 17).

İletişimin uluslararasılaşması sürecinde toplumsal ve kültürel etkileşimlerin yanı sıra enformasyonun değiş tokuşu da uluslararası bir nitelik kazanmaktadır. Enformasyon, ekonomik çlkarlara eklemlenerek tüketim nesnesi haline gelmiştir. $\mathrm{Bu}$ bağlamda, gelişmiş merkez ülkelerle, gelişmekte olan çevre ülkeler arasındaki ekonomik uçurumlar; enformasyonun yeni iletişim teknolojileriyle üretildiği merkez ülkelerden tek yönlü olarak, çevre ülkelere doğru akması sorununu da beraberinde getirmektedir. Bu durum, çevre ülkelerin merkez ülkelere olan bağımlılığını daha da arttırmaktadır. Enformasyonun dengesiz akışının yarattığı bu sorun, gelișmemiş ülkeler olarak nitelendirilen üçüncü dünya ülkelerini rahatsız etmiş ve çeşitli uluslararası platformlarda ortak çalışmalar yapmaya teşvik etmiştir.

$\mathrm{Bu}$ çalışmada, küreselleşme, enformasyon ve iletişimin uluslararasılaşmasındaki sorunlardan hareketle, ülkeler/uluslar arasındaki ekonomik, siyasal eşitsizlikler dolayımında ortaya çıkan enformasyon akışındaki dengesizlikler ve bunu düzenlemeye yönelik gerçekleştirilen uluslararası girişimler konu edinilmiştir. Çalışma, enformasyon akışındaki dengesizliklere ve bunu aşmaya yönelik gerçekleştirilen uluslararası girișimlerin genel bir değerlendirmesini yapmayı amaçlamaktadır.

Çalışma, enformasyon akışındaki dengesizliği çözme amacıyla başlatılan uluslararası girişimler başarılı mıdır? Ve sorun neden kapitalist bir bakış açısıyla, ülkeler/uluslar düzeyinden, çok uluslu şirketler düzeyine taşınmıştır soruları üzerine inşa edilmiştir. Enformasyonun dengesiz akışı bağlamında uluslararası toplumun söz konusu probleme yaklaşımını ve sorunun çözümü çerçevesinde oluşturulan mekanizmaları anlamak ve açıklamak üzere hazırlanan bu çalışmanın kapsamını, enformasyon dengesizliğinden ziyade bu dengesizliği ortadan kaldırma çabaları oluşturmaktadır. Çalışmanın sınırlılığı 
ise bu bağlamda gerçekleștirilen uluslararası girişimler olarak belirlenmiştir. Yukarıda belirtilen girişimlerin daha iyi anlaşılması ve süreçlerin daha net bir şekilde ortaya konulabilmesi için çalışmanın yöntemi olarak nitel betimsel analiz benimsenmiştir. Walcott (1994), nitel betimsel çalışmaların özgün formlarına bağlı kalarak doğrudan alıntılarla ve verilerin betimsel bir yaklaşımla okuyucuya sunulmasını ve araștırmacının bir öykü anlatıcısı gibi olayları belirli bir kronolojik düzen içerisinde anlatması gerektiğini ifade etmektedir. Bu anlamda çalışma, ele aldığı sorunun ve sürecin daha iyi anlaşılabilmesi için kronolojik bir sırada tasarlanmış ve çalışmada önce genel bir çerçeve çizebilmek adına küreselleşme, iletişimin uluslararasılaşması ve enformasyon toplumu kavramlarıyla konuya giriş yapılmıştır. Hemen ardından gelen Enformasyon Akışı, Akıştaki Dengesizlikler ve Elektronik Sömürgecilik başlığı altında çalışmanın temel problemi okuyucuyla paylaşılmıştır. Problemin tespiti sonrası sorunun çözümü için girişilen uluslararası girișimler Yeni Uluslararası Ekonomik Düzen, Yeni Dünya Enformasyon ve İletişim Düzeni, MacBride Raporu ve Dünya Bilgi Toplumu Zirvesi başlıkları altında tek tek değerlendirilmiştir. Çalışmanın son kısmında ise 'Sonuç ve Öneriler' bölümüne yer verilerek bazı çözüm önerilerinde bulunulmuştur.

Alanyazına bakıldığında enformasyon dengesizliği üzerine yapılmış çok sayıda çalışma olmakla birlikte, enformasyon akışındaki dengesizlikleri gidermek üzere gerçekleştirilen tüm uluslararası girişimleri tek bir potada eriterek birbirleriyle ilişkili bir şekilde sunmaya çalışan çalışmaların azlığı ve ilgili çalışmaların soruna karşı çözüm önerisi getirmemiş olmaları bu çalışmayı alanyazın açısından önemli kılmaktadır.

\section{Küreselleşme, İletişimin Uluslararasılaşması ve Enformasyon Toplumu}

Teknolojik gelişmelerle birlikte değerlendirilen küreselleşme olgusu, bir yandan yeni teknolojilerin gelişimini sağlayan diğer yandan da gelișen yeni teknolojilerin öncülüğünde ilerleme gösteren bir süreç olarak nitelendirilmektedir. Küreselleşme, en basit haliyle, dünyanın siyasal, ekonomik ve kültürel olarak tek bir mekân haline gelmesi olarak tanımlanmaktadır. Liberal argümanlara bakıldığında küreselleşme, dünya toplumlarının birbiriyle ilişkilerini ve bağlantılarını geliștiren ve birbirlerine eklemlenmeleriyle küresel demokrasiyi yaratacak, var olan eşitsizlikleri gidererek küresel ilerlemeleri sağlayacak bir tanımla olumlayıcı bir şekilde sunuluyor olsa da özüne bakıldığında, küreselleşmenin sunulandan farklı olarak kendi ideolojisini taşıyan bir kavram olduğu görülmektedir. $\mathrm{Bu}$ anlamda küreselleşme, neoliberal dünya görüşünün ideolojik bir söylemi olarak değerlendirildiğinde, kavramın çağdaş teknolojinin gerekleriyle uyum göstermekten ibaret bir süreç olmadığı, uluslararası sermayenin çıkar alanını dünya ölçeğinde genişletme projesinin somutlaşmış bir iradi ifadesini oluşturduğu görülmektedir (Yeldan, 2008, s. 20). Tarihsel süreç içerisinde baktığımızda küreselleşme kavramının ekonomik ve siyasal güç odağı ülkelerin (gelişmiş ülkeler/merkez ülkeler/kuzey ülkeleri) ideolojik çıkarları noktasında ele alındığı bilinmektedir. Söz konusu ülkeler, var olan ideolojik çıkarlarını, kavramın varoluşsal bulanıklığı yardımıyla gizlemekte, gelişmekte olan üçüncü dünya ülkelerini (gelişmemiş ülkeler/çevre ülkeler/güney ülkeleri) modernleşme kuramları adı altındaki uygulamalarla geliştireceklerini ve ekonomik olarak kalkınmalarının sağlanacağı yönündeki telkinlerle sisteme entegre etmektedirler. $\mathrm{Bu}$ şekilde küreselleşme kavramı giderek güçlenmekte, fakir çevre ülkelerin dünya ekonomisi ile bütünleşecek politikalarla zenginleșecekleri ileri sürülmektedir (Gürkan, 2001, s. 14). Bugün küreselleşme olgusuna tekrar bakıldığında, liberal argümanlarda çevre ülkelere vaat edilenlerin gerçekleşmediği, modernleşme kuramlarının başarıya 
ulaşmadığı; küreselleşmenin sadece gelişmiş ülkelerin ekonomik, siyasal ve kültürel iktidarlarını pekiştirdiği ve daha ileri boyutlara taşıdığı gerçeği ile karşılaşılmaktadır.

Küreselleşmeyle birlikte yaşanan iletişimin uluslararasılaşması, ülkeler arasındaki ilişkilerin ekonomik, kültürel ve siyasal dengesizliklerin iletişim boyutunu da gözler önüne sermektedir. Bu bağlamda dünyadaki jeopolitik gelişmelerin, savaşların, politik ve ekonomik kutuplaşmaların ve birleşmelerin arkasındaki temel motif; kapitalist birikim, yoğunlaşma, merkezileşme, tekelleşme ve asıl olarak kar güdüsüdür (Güzelsarı, 2012, s. 235). Kapitalist sistemle iç içe geçmiş bir küreselleşme anlayışı da merkez ülkelerin ekonomilerinin kar odaklı ilerlemesi ve çevre ülkelerin bu ülkelere bağımlı olması durumunu ortaya çıkarmaktadır. Yeni iletişim teknolojilerinin merkez ülkelerin tekelinde olması, başta ekonomik eşitsizlikler bağlamında çevre ülkelerin merkez ülkelere olan bağımlılıklarını sürekli olarak artırmaktadır.

Enformasyon toplumu kavramı, günümüz toplumlarını tanımlamak için sıkça kullanılan ifadelerden biridir. En basit haliyle bir bildirme, bilgilendirme süreci olan enformasyon, sanayi toplumundan sonraki toplumsal yapının temel taşı niteliğindedir. Sanayi toplumundan enformasyon toplumuna geçiş sürecinde, toplumsal üretim yapısı ve biçimi üzerinde ciddi dönüşümler yaratmıştır. Sanayi toplumunda üretim, makinalar aracılığıyla gerçekleştiriliyorken; enformasyon toplum yapısında üretim ise teknolojiler ve bu teknolojilerin gelişimini sağlayan enformasyon ağları aracılığıyla gerçekleștirilmektedir. Eski toplum yapısında ülkenin gelişim durumu sanayileşmesi ölçeğinde değerlendiriliyorken, yeni toplum yapısıyla birlikte sahip olunan enformasyon, yeni enformasyonun üretimi ve enformasyonun işlenmesine yönelik var olan teknolojik altyapının kullanımıyla değerlendirilmektedir. Bu anlamda ülkeleri/ulusları, enformasyon üretebilenler ve üretemeyenler, enformasyona ulaşabilenler ve ulaşamayanlar şeklindeki kategorilerde değerlendirmek mümkündür. Kategoriler arasındaki uçurumun giderek açılması, enformasyon devriminin uluslararası gelişmişlik düzeyleri arasındaki farkı azaltacağı iddialarının aksine, uluslararası gelişmişlik farkını giderek artırdığı gözlemlenmektedir.

'Enformasyon toplumu' nitelemesiyle, toplumsal ölçekte bir enformasyon yayılımını anlatmayı hedefleyen tanım, enformasyona sahip olan kesimlerin lehine gelişmelerin yaşandığı gerçeğini gizlemektedir. Tanım, oluşum itibariyle merkez ülkeler tarafından belirlenmiştir. Gelişmekte olan veya az gelişmiş ülkeler için gelişmiş ülkeler tarafından belirlenmiş enformasyon toplumu politikaları çerçevesi vardır (Başaran, 2004, s. 15). Bu durum, dengesizliği vurgulayacak bir ifadeyle 'egemen senaryo' olarak adlandırılmaktadır (Van Audenhove, Burgelman, Nulens, \& Cammaerts, 1999, s. 389). Dolayısıyla enformasyon toplumunun ekonomik ve siyasal iktidar sahiplerinin güdümünde olduğu ve genel anlamıla bütün toplumların enformasyona erişemediği görülmektedir. Küresel çaptaki iktidar odakları sürekli değişmemekte, iktidar sahiplerinin ardılları sistemin sürekliliği noktasında yerlerini almaktadır. Enformasyona ve gelişen teknolojilere erişimi mümkün olmayanlar, ekonomik, siyasal ve kültürel bağlamda gelişme sağlayamadıkları gibi, enformasyon devriminin olumsuz etkilerini de derinden yaşamaktadırlar. Dünyadaki herkesin enformasyona eşit düzeyde ulaşamaması nedeniyle, çevre ülkelerin merkez ülkelerle olan gelişmişlik düzeylerindeki farkın açılmasına neden olan tehditler yaratan bir boyutu da beraberinde getiren enformasyon toplumu kavrami; enformasyonun sahipliği ve teknolojik altyapının kullanımı bağlamında iktidar yapılarını pekiştirici etkisiyle bu tehlikeyi daha büyük boyutlara ulaştırmaktadır. 
Enformasyon toplumunun ekonomik, siyasal ve kültürel olmak üzere 3 boyutu olduğunu öne süren Hamelink (1991a, s. 20-21), kullanılan enformasyon tekniklerinin, kapitalist üretim biçimini hakim kılarak sonsuzlaştırma çabasının kusursuz araçları olarak ekonomik; merkezileşmeye dayalı denetim sistemini önceki uygulamalarla karşılaştırılamayacak denli kolaylaştırıcı olması nedeniyle siyasal; enformasyon teknolojisindeki gelişmelerin özerk, özgün ve farklı kültürel oluşumlara olanak tanımadığını, aksine dünya çapında egemen, başat ve tek bir kültürün oluşumuna katkıda bulunduğunu ve yerel kültürleri yok etmekte olduğunu belirterek kültürel boyutlarından bahsetmektedir. Batılı gelişmiş ülkeler ve onların yönetimindeki ulus ötesi ve çok uluslu şirketler, kapitalist sistemin süreklilik kazanmasıyla elde ettikleri ekonomik ve siyasal üstünlüklerinin yanına kültürel üstünlüğü de ekleme çabası içerisindedirler. Bu üstünlüğü devam ettirebilmenin en etkili yolunun ise sistemi meşrulaştırarak enformasyon sahipliğini tekellerinde bulundurmalarıla mümkün olduğu görünmektedir.

Enformasyonun yaygınlaşmasıyla bilgi iletişim teknolojileri de gelişmekte ve bunları üretebilen ve sahip olabilen ülkeler, ekonomik, toplumsal ve kültürel anlamda gelişmektedirler. $\mathrm{Bu}$ durum, gelişmiş ülkeler ile gelişmekte olan ülkeler arasında enformasyona ulaşma noktasında dijital uçurum sorununu da yaratmaktadır. Sayısal bölünme olarak da bilinen dijital uçurum, ekonomik yetersizlikler sebebi ile bilgi iletişim teknolojilerine ulaşamayan ya da sinırlı olarak ulaşabilen toplumlar ile bunlara ulaşan hatta üreten toplumlar arasındaki fark olarak tanımlanmaktadır (Değirmen, Akıncı, \& Özbükerci, 2016, s. 109). Diğer bir ifadeyle, gelişmiş ülkeler açısından toplumun bir kesiminin yeni enformasyona erișebilmesi, bir kesiminin ise söz konusu bu ağın dışında kalması durumu olarak, uluslararası düzeyde ise gelişmiş ülkeler ile gelişmekte olan ülkelerin enformasyona erişim açısından "enformasyon zenginleri ve enformasyon yoksulları”nı ortaya çıkarmaktadır (Geray, 2003, s. 135). Yeni teknolojilerin yüksek maliyetli olması, beraberinde altyapı sorunlarını getirmekte ve teknolojik anlamda uzmanlık gibi gereklilikler çevre ülkeleri, Batılı merkez ülkelere bağımlı kılmaktadır. Bu bağımlılık gelişmiş ülkelerle gelişmekte olan ülkeler arasında ekonomik ve sosyo-kültürel farklılıkları daha da artırarak enformasyona erişim noktasında dijital uçurumun giderek artmasına neden olmaktadır. Çevre ülkelerdeki iletişim sistemlerinin ve bu araçların ürettiği mesajların gerçek kaynağı ve biçimlendiricisi Batılı merkez ülkelerdir. Çevre ülkelerin çoğu, kendi tarihlerini, gereksinimlerini, ilgilerini, değerlerini ve kültürlerini yansıtmak amaciyla kendi iletişim sistemlerini kuracak, kurumsallaştıracak maddi kaynaklardan ve teknik elemanlardan yoksun durumdadır (McPhail, 1991a, s. 183-184). Dijital uçurum olarak da kavramsallaştırılan bu durumla ortaya, ekonomik ve enformatik iki ayağı olan kısır bir döngü çıkmakta, ekonomik gücü olmayan ülkeler/uluslar enformasyona ulaşamamakta ve enformasyona ulaşamayan ülkeler/uluslar enformasyon üretemeyerek ekonomik bir çıktı sağlayamamaktadırlar. Bu nedenle söz konusu kısır döngünün kırılmasında enformasyon akışındaki dengesizliğin giderilmesi anahtar bir rolle karşımıza çıkmaktadır.

\section{Enformasyon Akışı, Akıştaki Dengesizlikler ve Elektronik Sömürgecilik}

Tarih boyunca ülkelerin ilerleme hızlarında görülen dengesizlik, küreselleşme süreciyle birlikte artmış; ekonomik, siyasi ve kültürel alanda artarak devam etmiştir. Giderek artan bu dengesizliklerden biri de enformasyon akışındaki dengesizliktir. Küreselleşme ve dijitalleşmeyle birlikte merkez ve çevre ülkeler arasındaki farkın büyük bir hızla açılması, bilgi ve iletişim teknolojilerindeki (BİT) gelișmeler, enformasyon akışındaki zaten 
dengesiz olan durumu daha da derinleştirmiştir. Bu noktada dijital devrim, enformasyon dengesizliğinin artışında önemli bir çarpan olarak karşımıza çıkmaktadır.

Enformasyon dengesizliği, genellikle haber akışı ve enformasyonun serbest dolaşımı üzerinden anlatılan bir eşitsizlik durumu olarak ele alınır. Bu tanımlama aslında yanlış da değildir. Ancak enformasyon dengesizliğinin sonuçlarına ve etkilerine bakıldığında, dengesizliğin ulusal bağımsızlıktan ekonomiye, üretim ilişkilerinden turizme kadar çok yönlü bir etkiye sahip olduğu görülmektedir. Dolayısıyla bu tanımlama biçimi, olayların etki ve sonuçlarını göz ardı eden eksik bir tanımlamadır. Nitekim Akdemir (2002, s. 240), teknolojik yenilikler ve toplumsal karmaşıklıklar nedeniyle egemenlik kavramının giderek artan bir oranda enformasyon aracılığıyla tanımlanır olduğundan bahsederek, sınırlar ötesi bilgi akışı, bilgi bankaları, doğrudan yayın uyduları, uzay spektrumu ve bu yöntemleri kullanan uluslararası şirketlerin üretimsel, endüstriyel, mali ve idari etkinlikleri, diğer ülkelerin özellikle de üçüncü dünya ülkelerinin ekonomik ve siyasal egemenlikleri üzerinde ciddi bir tehdit oluşturduğunu ifade etmektedir. Özetle tekrarlamak gerekirse enformasyon dengesizliği, çok yönlü sonuçları olan ülkelerin/ ulusların varoluşsal bir mücadele alanıdır.

Merkez ülkelerin enformasyon üzerinde artan egemenliği, merkez ülkelerle çevre ülkeler arasında ciddi boyutlara ulaşan bir enformasyon dengesizliği yaratmaktadır. Bu dengesizliğin oluşumunda en etkili faktör enformasyonun işlenebilmesine yönelik altyapı sorunlarıdır. Batılı ülkeler ekonomik ayrıcalıklarını teknik ve altyapısal donanımlarıyla destekleyerek enformasyonu daha etkili şekilde kullanmakta ve yeterli donanıma sahip olmayan çevre ülkelere enformasyon akışını tek yönlü olarak sağlamaktadırlar. Böylelikle, uluslararası enformasyon akışında dengesiz bir yapı oluşmakta ve enformasyon, tüm dünyada gelişmiş merkez ülkeler arasında dolaşarak merkez ülkelerle çevre ülkeler arasındaki enformasyon akışı tek yönlü bir görünüm arz etmektedir. Söz konusu tek yönlü akış, büyük ölçüde çevre ülkelerden gelen ham enformasyondan oluşmaktadır. Oysa gelişmiş, Batılı merkez ülkeler, çevredeki gelişmemiş ülkelere diğer tüketim eşyalarıyla birlikte, kullanıma hazır enformasyon paketleri göndermekte ve çevredeki ülkelerin işlenmemiş ürünleri, yine çevredeki ülkelere bu kez çok daha pahalı bir fiyatla işlenerek satılmaktadır (Hamelink, 1991b, s. 262-263). Dolayısıyla Batılı merkez ülkeler tarafından çevre ülkelere yönelik tüketim yönlendirmesi yapılmakta, ancak üretimin nasıl gerçekleştirildiğine dair enformasyon sağlanmamaktadır. Gelişmekte olan ülkelere enformasyon götürerek bu ülkelerin modernleşmesinde etkin rol oynayacağını iddia eden merkez ülkeler, gelişmekte olan ülkelerin kitle iletişim araçlarının kullanımına müdahale etmekte, enformasyon akışıyla kendi değerlerini, kültürlerini bu ülkelere dayatmaktadırlar. Aynı zamanda ekonomik ve ideolojik güçleriyle yeni iletişim teknolojilerinin üretimini yapmakta, bu araçların kullanımıyla da gelişmemiş ülkeler üzerinde baskı oluşturmaktadırlar. Geçmişte toprak istilası yoluyla gerçekleştirilen sömürgeciliğin etkisini yitirmesi ve günümüzde yeni bir biçim almasıyla merkez ülkeler, kendi sömürgeci amaçlarını yeni iletişim teknolojileri ve enformasyonu ellerinde bulundurmaları yoluyla gerçekleştirmektedirler. Bu yeni sömürgeci amaçlar bağlamında enformasyonun tek yönlü akışı, çevre ülkelerin gelişimlerini merkez ülkelerin çıkarları odağında şekillendirmekte ve var olan ekonomik uçurumları genişleterek çevre ülkelerin bağımlılığını giderek artırmaktadır. Emperyalizmin askeri ve ekonomik temelini yitirmiş olması, bugün daha çok kültür ve yaşam stilleri noktasında kurulan, yeni bir kültür yayılımıyla gerçekleștirilen asimileye yönelik emperyalizmi söz konusu yapmaktadır. $\mathrm{Bu}$ yeni emperyalizm biçimi, kültür emperyalizmi veya kültürel bağımlılık olarak 
nitelendirilmektedir (Mohammadi, 1991, s. 326). Hepimizin bildiği şekliyle bu durum, 'kültürel emperyalizm' olarak da adlandırılmaktadır.

Kültürel emperyalizm, aslında birbiriyle ilişkili fakat birbirinden farklı süreçlerin toplamıdır. İşletilen bu süreçlerin sonunda ülkelerin/ulusların kendilerine özgü kültürel kodları değișerek, dönüșerek egemen olanınkine benzer bir hale gelmektedir. İletişim teknolojileri aracılığıyla gerçekleştirilen bu emperyalizm türünü McPhail (1991b, s. 150) 'elektronik sömürgecilik' olarak nitelendirmiş ve iletişim araç ve gereçleri aracılığıyla, değişen ölçülerde ve boyutlarda yabancıların değerlerini, yaşam biçimlerini ve beklentilerini egemen kllarak yerli ve özgün kültürleri; ulusal düzeyde gerçekleștirilmeye çalışılan toplumsallaşma süreçlerini değiştirebilecek bir bağımlılık ilişkisi olarak tanımlamıştır.

\section{Dengesiz Akışa Karşı Uluslararası Girişimler}

Çalışmanın başından beri üzerinde durulan iletişim, enformasyon ve enformasyon dengesizliğinin, çevre ülkeler için ifade ettiği anlam ve önem açısından yarattığı rahatsızlık, önce ekonomik temelde NIEO fikrini, ardından da onun ekonomik amaçlarının iletişim alanına yansıyan paralelliğinde NWICO fikrini tetiklemiştir. NWICO'nun bir sonucu olarak ortaya çıkan MacBride Raporu'ndaki tespitler, konunun netleşmesi adına önemli bir gelişme olurken, dengesizliğe karşı gerçekleștirilen son uluslararası girişim ise WSIS olmuştur.

\subsection{Yeni Uluslararası Ekonomik Düzen (NIEO)}

İkinci Dünya Savaşı sonrasında yaşanan ekonomik ve siyasal anlamdaki küresel değişim, Amerika Birleşik Devletleri (ABD) ve Sovyet Sosyalist Cumhuriyetler Birliği (SSCB) güdümünde devam eden iki kutuplu bir sistemi ortaya çıkarmıștır. Söz konusu kutuplardan kapitalist, Batılı merkez ülkelerin pek çok alandaki üstünlükleri ve bu üstünlüklerin bir sömürü aracı olarak kullanılması, sömürülen ülkeleri gittikçe daha da zorlamıştır. $\mathrm{Bu}$ süreçte sömürge ülkeler olarak güçlü devletlerin boyunduruğu altında bulunan çoğu çevre ülke, yaşanan değişimlerden faydalanarak siyasi özgürlüklerini ilan etmişlerdir. Ancak söz konusu siyasi özgürlügün aslında tam olarak istedikleri şeyin küçük bir parçası olduğunu anlamaları çok da uzun sürmedi. Çünkü tek başına siyasal özgürlük, görünürde bir özgürlüktü, içi boştu ve şekilseldi. Ekonomik özgürlük olmadan siyasal özgürlük tek başına çok da bir anlam ifade etmiyordu. Bu anlamda Ansah (1991, s. 199), söz konusu değişimler sonucu elde edilen özgürlüğün sadece siyasal alanla sınırlı kaldığını, ekonomik ilişkilerdeki bağımlılık durumu değişmeden devam ettiğini belirtmiştir.

Batılı merkez ülkeler, çevre ülkelerin özgürlüklerini kazanmasıyla sekteye uğrayan sömürge kazanımlarını kaybetmemek için sömürgeci yaklaşımlarındaki şekli değiştirmek zorunda kalmışlardır. Bu bağlamda kendilerini modern dünyanın rol-model ülkeleri olarak sunan merkez ülkeler, modernleştirme adıyla olumladıkları 'Gelişme ve Kalkınma' kuramlarını, çevre ülkelere ulaşılması gereken bir hedef olarak göstermişlerdir. McPhail'in (1991a, s. 170) ifadesiyle bu hedef, çevre ülkelerin bekledikleri gelişmeyi, ekonomik büyümeyi sağlayacak koşulların oluşturulması ve tüm geleneksel unsurların yıkılmasıyla birlikte, modernleştirmenin göstergesi olarak nitelendirilebilecek ögelerin sürekli olarak yaygınlaştırılarak, modern toplumun gerçekleştirilmesi için gerekli ortamın yaratılması şeklinde ortaya çıkmıştır. Bu kuramlar, merkez ülkeleri idealize ederek çevre ülkelerinin de merkez ülkeler gibi davranarak kalkınabileceklerini iddia etmekte, ancak modernleșme sürecinde merkez ülkelerin karşılaştıkları olumsuzlukları, başarısızlıkları, çevre ülkelerdeki farklı toplumsal, siyasal, tarihsel hatta kültürel yapıları ve iç dinamikleri 
göz önünde bulundurmamaktadır. Bu nedenle, dönemin kutsanan söz konusu popüler modellerine bugün dikkatli bir şekilde bakıldığında, modernleşme kuramlarının iddia edildiği gibi çevre ülkelerin gelişmesinde etkili olamadığı net bir şekilde görülmektedir.

Siyasal özgürlüğün tek başına, tam bağımsızlık anlamına gelmediğini gören çevre ülkeler, siyasal özgürlüklerini kazandıktan sonra aslında ekonomik özgürlüklerini henüz elde edemediklerini fark etmişler, uluslararası ekonomik eşitsizliklerin giderek büyüdüğüne tanık olmuşlardır. Tam bağımsızlık yolunda özgürlüklerin genişletilmesi, çevre ülkeler için hayati bir konu olmuştur. Bu konu üzerine odaklanan çevre ülkeler, dünya ekonomik sisteminin kontrol mekanizmalarının gelişmiş ülkelerin tekelinde olmasına karşı çıkmış ve 'Bağlantısızlar Hareketi' olarak örgütlenerek 'Yeni Uluslararası Ekonomik Düzeni'nin (New International Economic Order - NIEO) oluşturulmasına yönelik taleplerini ortaya koymuşlardır. Bu taleple çevre ülkeler, 1970'lerde dünya ekonomisindeki gelişmeler içerisinde, Kuzey - Güney ülkeleri arasındaki eşit ilişkilere dayalı, yeryüzünden yoksulluğu kaldırmayı amaçlayan, Güney'in ekonomik yönden kendi kendine yeterli hale gelmesini öngören yeni bir uluslararası ekonomik düzen yaratmak istemişlerdir. Talep edilen bu düzen, var olan uluslararası ekonomik ve siyasal güç yapısının değişmesini ve az gelişmiş ülkelerin dünya ekonomisinde etkin bir rol oynamalarını sağlamayı hedeflemiștir (Seyidoğlu, 1980, s. 263).

Kapitalist sistemin sermaye sahibi merkez ülkeler yararına işleyen kuralları, çevre ülkeleri daha da fakirleştirmekte, bu ülkeleri ekonomik, teknolojik ve sosyo-kültürel anlamda Batılı merkez ülkelere bağımlı hale getirmektedir. Bu durum, çevre ülkeler açısından yeni bir ekonomik düzeni zorunlu kılmıştır. 1974 yılı Nisan’ında Birleşmiş Milletler Genel Kurulu'nun özel oturumunda uzun tartışmalardan sonra Yeni Uluslararası Ekonomik Düzen'in (NIEO-YUED) kurulması ilke olarak kabul edilmiş ve bu konuda bir deklarasyon ve eylem planı benimsenmiştir (Seyidoğlu, 1980, s. 269).

Merkez ülkelerin yeni bir ekonomik düzene karşı olan isteksizliği, Yeni Uluslararası Ekonomik Düzen çabalarına rağmen, değişimi neredeyse imkânsız kılmış, merkez ülkelerle çevre ülkeler arasındaki uçurum hızla artmaya devam etmiştir. Uçurumun artış hızı, var olan eşitsizliklerin sadece ekonomik düzenlemelerle halledilemeyeceğini göstermiştir. Kapitalist sistemin gelişen enformasyon ve yeni iletişim teknolojileriyle eklemlenmesi, merkez ülkelerle çevre ülkeler arasındaki gelişim farklılıklarını daha da aşılmaz hale getirmiştir. Merkez ülkelerin kendi çıkarlarını gerçekleştirmek amacıyla kullandıkları enformasyon teknolojileri bir yandan küreselleşme sürecini daha da hızlandırırken, diğer yandan hem çevre ülkelerin ekonomik bağımlılığı başta olmak üzere bağımlılıklarını pekiştirmekte hem de kültürel anlamda asimilasyonu ve entegrasyonu sağlamaya çalışmaktadır.

\subsection{Yeni Dünya Enformasyon ve İletişim Düzeni (NWICO) Süreci}

Yeni Dünya Enformasyon ve İletişim Düzeni (NWICO), Yeni Uluslararası Ekonomik Düzen (NIEO) tartışmalarından hareketle, paralel isteklerin iletişimle alakalı bir türevini oluşturmaktadır. Aslında pek çok noktada NIEO taleplerinin ve bu taleplerle elde edinilmek istenilen çıktıların NWICO'yla yakından ilişkili olduğunu da söylemek mümkündür. Yani NIEO olmadan NWICO’yu ve NWICO olmadan da NIEO'yu gerçekleştirmek imkânsız gibidir. Sonuçta her iki girişim de temelde bağımsızlıkla ilgilidir.

NWICO tartışmaları, yeni bir uluslararası ekonomik düzen için Güney'in bağımlı olmayan ülkelerinden yapılan çağrılarla ilişkilidir. Söz konusu bu çağrılar, kendine yeterlilik ve 
devlet egemenliği için kendi gerekçelerine sahip Sovyetler Birliği liderliğindeki Doğu Bloğu'nun sosyalist ülkeleri tarafından da desteklenmiştir (Mansell \& Nordenstreng, 2006, s. 17). 1970'lerin dünya düzeninde tarafsız ülkeler, daha adaletli dünya arayışı yönünde, 1974'te NIEO talebiyle gelirken, ardından bu taleple ilgili uğraş ve gelişmeler hızlanmış, bu talebe 1976'da NWICO talebi de eklenmiştir. Bu çerçevede NWICO talebi dört ana konuyu ve problemi dile getirmiş ve bunlara yönelik çözüm arayışına girmiştir (Erdoğan, 1995, s. 253-254):

1. Az gelişmiş ülkelerin kendi enformasyon kaynakları üzerinde karar verme hakları olduğu,

2. Az gelişmiş ülkelerin haberlerinin Batı pazarında tercihli muamelesi gereği; az gelişmiş ülkeler hakkındaki haberlerin ve programlarının Batıda artması istemi; dünya iletişim düzenindeki dikey iletişim yapısı yerine yatay iletişim yapısının teşvik edilmesi,

3. Az gelişmiş ülkelere ileri iletişim teknolojilerinin direkt yardım ve bağışla sağlanması,

4. AP, AFP, REUTERS ve UPI'ın az gelişmiş ülkelerdeki faaliyetlerinin yeniden düzenlenmesi.

Bu dört konu ve problem üzerinden, merkez ülkeler lehindeki enformasyonun tek yönlü akışıyla birlikte, merkez ülkelerin çevre ülkeler üzerindeki yeni sömürgecilik faaliyetleri de engellenmeye çalışılmıştır. Çevre ülkeler olarak jeopolitik adlandırmaya tabi tutulan üçüncü dünya ülkelerinin kendine yeterliliğine vurgu yapılarak, kendi kaynaklarının denetimine yönelik teşvikte bulunulmuş ve yeni iletişim teknolojileri noktasında sahiplik ve kullanım farklılıklarının yardımlar dolayımında en aza indirilmesi amaçlanmış ve haber ajanslarındaki eşitsiz temsil sürecinin düzenlenmesine de atıfta bulunulmuştur. Bu bağlamda NWICO'nun demokratikleştirme, dekolonizasyon, tekelleşmenin yok edilmesi ve kalkınma şeklinde dört temel yapı taşı bulunmaktadır. Bu temel yapı taşları yeni düzenin tartışmalarında defalarca tekrarlanan temaları temsil etmektedir. $\mathrm{Bu}$ temaları: Haber akışları "tek yönlü akışlar" olarak nitelendirilir ve ülkeler arasında daha adil bir haber akış dengesinin sağlanması için gereken önlemler alınır (demokratikleşme); 'tek yönlü akış' ve yanlış beyanlar, hizalanmamış ülkeler için büyük önem taşıyan bir konu olan ülkelerin kültürel kimliklerine saygının eksikliğini yansıtacak şekilde yorumlanmıștır (sömürgeleşme); uluslar üstü şirketlerin iletişim teknolojisi açısından tekel statüsü, ulusal bağımsızlığa karşı bir tehdit olarak algılanmaktadır (demonopolizasyon); kalkınma sürecinde kitle iletişim araçlarının yaşamsal rolü vurgulanmakta ve hizalanmamış ülkeler, dünyadaki iletişim kaynaklarının daha adil bir dağıtımını talep etmek için bir araya gelmektedirler (kalkınma), şeklinde sıralamak mümkündür (Calsson, 2003, s. 40-41).

$\mathrm{Bu}$ amaç ve yapı taşlarından hareket eden NWICO, ilk kez UNESCO'nun Mart 1976'da Tunus toplantısında gündeme getirilmiștir. Bu toplantı sonunda hazırlanan rapor, yeni uluslararası iletişim düzeninin temeli olarak değerlendirilebilir. Ardından Mart 1976'da Honolulu'da, Mayıs 1976'da Meksika ve Temmuz 1976'da da Yeni Delhi'de yapılan toplantılarda Tunus'ta alınan kararlar olgunlaştırılmıştır.

\subsection{MacBride Raporu}

1976'de Nairobi'de toplanan UNESCO Genel Konferansı, uluslararası iletişime ilişkin sorunların bir uluslararası komisyona inceletilmesi yolunda bir karar almıştır (Uluç, 2003, s. 159). Birkaç ay sonra Genel Direktör, çağın toplumundaki iletişim sorunlarının 
tümünü inceleme işini Sean MacBride başkanlığında oluşturulan bir komisyona vermiştir. Komisyonun hazırladığı rapor, NWICO sürecinde çevre ülkelerin küçük bir zaferi olarak değerlendirilebilecek şekilde, söz konusu dengesizliğin UNESCO tarafından da onaylanması anlamına gelmiştir.

Sean MacBride başkanlığındaki komisyon, görevlerinden hareketle hazırladı̆̆ı raporu (ileride başkanının adıyla anılacak olan) 1979'da teslim etmiştir (Uğur, 1991, s. 241). MacBride Raporu'nun değerlendirmesine geçmeden önce, oluşumunu ve geleceğini hazırlayan ‘Büyük Küresel Medya Tartışması'nın aşamalarına değinmek raporun içeriğini anlamak açısından yararlı bir zemin oluşturacaktır. Bu çerçevede analitik amaçlar doğrultusunda yapılan tartışma, beş ana aşamadan oluşmaktadır ancak raporun teslim edildiği tarihe kadar olan ilk üç maddesi aşağıda belirtilmiştir (Mansell \& Nordenstreng, 2006, s. 21-22) (Nordenstreng, 2010, s. 6):

1. 1970 - 1975 Sömürgeciliği engelleme: Bu süreçte gelişmekte olan ülkelerde endüstrileșmiş Batıya karşı bir saldırı hakimdi ve bu aşama, enformasyon emperyalizmi fikri ve BM tarafından önerilen Yeni Bir Uluslararası Enformasyon Düzeni kavramını içermekteydi.

2. 1976 - 1977 Batı karşı atağı: Dünya Basın Özgürlüğü Komisyonu’nun kurulduğu, Nairobi'de UNESCO'nun Kitlesel Medya Deklarasyonu'nun gecikmeli tanıtımının yapıldığl, "Telekomünikasyon için Marshall Planı” önerisini içermekteydi.

3. 1978 - 1980 Mütareke: UNESCO’nun Kitlesel Medya Deklarasyonu'nun kabul edilmesi, MacBride Komisyonu'nun çalışma ve raporu, Yeni Enformasyon ve İletişim Düzeni konusundaki fikir birliği, iletişimin geliştirilmesi için Uluslararası Programın Kurulması (IPDC).

Küresel bağlamda siyasal ve ekonomik süreçlerin ülkeler arasındaki ilişki ve dengeleri nasıl etkilediğini anlamak ve bunlar dolayımında ortaya çıkan iletişim ve enformasyon akışındaki eşitsizlik sorunlarının anlaşılması için bu aşamaları bilmek önem taşımaktadır. Özellikle ilk 2 aşama MacBride Raporu'nun hazırlanmasına giden süreçte, siyaset ve ekonomik dengelerinin nasıl etkili olduğunu ortaya koymaktadır. 1978-1980 mütareke dönemini ise aslında 1979'da teslim edilen raporun içeriğinin çevre ülkeleri rahatlatması olarak değerlendirmek de mümkündür.

Komisyona verilen görev; düşünce ve çalışmaların yönelmesi gereken belli başlı dört noktada toplanmıștır. Bu bağlamda komisyondan beklenenleri, iletişim ve enformasyon alanında var olan durumu incelemek, ulusal düzeyde yeni bir eylem ve uluslararası düzeyde de bütünsel ve uyumlu bir yaklaşım gerektiren sorunları belirlemek; UNESCO Genel Konferans kararlarına uygun olarak, dünyada özgür ve dengeli enformasyon dolaşımı sorunlarına gelişmekte olan ülkelerin özgün gereksinimlerine özel bir dikkat göstermek; yeni bir ekonomik düzen kurulması ve 'yeni bir iletişim düzeni'nin kurulmasını kolaylaştırmak için yapılacak girişimler ışığında iletişim sorunlarını çeşitli görünümleri altında çözümlemek ve son olarak dünyanın karşı karşıya bulunduğu büyük sorunlar üzerinde kamunun bilinçlenmesinde iletişimin oynayabileceği rolü belirlemek, onu bu sorunlara karşı duyarlı hale getirmek ve bunların ulusal ve uluslararası düzeyde planlı eylemlerle çözümüne yardımcı olmak şeklinde sıralamak mümkündür (MacBride, 1993, s. 45-46).

Temelde 6 kısımdan oluşan MacBride Raporu'nda her kısım kendi içinde farklı bölümlere ayrılmıștır. Rapor, iletişim ve enformasyonun tarihsel süreçlerinin ayrılmasından hareket 
ederek, bu iki kavramın küresel ve yerel bağlamdaki önemini ve yaşanılan sorunları tartışmanın odağına almaktadır. Komisyon üyeleri, yeni evrensel habercilik ve iletişim düzeninin, koşul ve uygulamalardan oluşan bir bütün olmadığını, daha ziyade bir süreç olduğunu belirtmektedirler. Bu sürecin görünümleri durmadan değişmektedir ancak amaçlar sabittir. Bu amaçları adalet, hakkaniyet, haber alışverişinde daha çok karşılıklılık, iletişim akımlarına daha az bağımlılık, yukarıdan aşağıya daha az bildiri dağıtımı, kendi kendine yeterlilik ve kültürel kimliğin korunması şeklinde sıralamak mümkündür (MacBride, 1993). Bu amaçların ortak hareket noktası ise hiç kuşkusuz enformasyon akışındaki dengesizlik ve eşitsizliğin sonlanmasına yönelik yeni bir iletişim ve enformasyon düzeni kurulmasıdır. Her ne kadar rapor, temeline yeni bir iletişim ve enformasyon düzenini (NWICO) alıyor olsa da (Nordenstreng, 2010, s. 11) belirttiği şekilde, teknoloji ve altyapıların sosyo-ekonomik politikalar ve politik ilkelerle yakından bağlantılı olduğu ve özgürlük ve sorumluluğun bölünmez olarak anlaşıldığı iletişim sorunlarına kapsamlı bir yaklaşım gereğini onaylarken, NWICO kavramı belirsiz ve aslında tamamlanmamış kalmıştır.

Carlsson'a (2003, s. 46) göre raporun sonunda yer alan ve 82 maddeyle oluşturulan önerilerin düzenlendiği kategorilerin içeriği çok açıktır. Bu önerileri, "Bağımsızlığı ve Özgelişmeyi Güçlendirmek", "Toplumsal Sonuçlar ve Yeni Görevler”, "Mesleki Kurallar ve Standartlar", "İletişimin Demokratikleșmesi" ve "Uluslararası İş Birliğinin Gelişmesi" başlıkları altında toplamak mümkündür. Raporda, yeni iletişim teknolojilerinin hızlı bir gelişim göstermesinin, küresel anlamda bir ilerleme yaratmayacağı belirtilirken, az sayıda ülke ve bir ülke içinde de az sayıda insanın bunlardan yararlanabildikleri ve bu buluşların gerçekleștiği birkaç ülkenin, gelişmenin zorluklarla sürdürüldüğü ve gerekli altyapıların gerçekleşmesine izin vermeyen bir yoksulluk tarafından yavaşlatıldığı ülkeler üzerinde büyük bir üstünlüğe sahip olduğu belirtilmektedir (MacBride, 1993, s. 13). Bu durum ekonomik koşulların, iletişim üzerinde de etkili bir faktör olduğunu göstermektedir. Bu çerçeveden bakıldığında ekonomik gelişmişlikle teknolojik gelişmişlik arasında pozitif bir ilişki olduğu ortadadır. Ekonomik olarak gelişmiş ülkeler teknolojileri ve enformasyonu hem üretip hem de kullanabilmektelerken, ekonomisi zayıf ülkeler teknoloji ve enformasyonu ne üretebilmekte ne de kullanabilmektedirler. İletişimin ve enformasyonun metalaştığı çağımızda, çevre ülkelerin teknoloji ve enformasyonu kullanamıyor olması, merkez-çevre ülkeler arasındaki eșitsizlikleri daha da derinleștirmektedir.

İletişim hakkı, enformasyona ulaşma, erişme ve enformasyonu kullanma özgürlüğünü kapsamaktadır. Ancak alana büyük ekonomik yatırımların gerekliliği, çevre ülkelerin bu haklardan yeteri derecede yararlanamamasına neden olmaktadır. Üstelik bu hak, siyasal bağlamda da uluslararası egemen güçlerin, iktidarlarının yararına olacak şekilde kullanılmakta, gelişmekte olan ülkelerin ekonomik yetersizliklerinden kaynaklanan bir durum, bu ülkeleri uluslararası düzeyde hem ekonomik hem siyasal olarak müdahaleye açı hale getirmektedir. Enformasyon özgürlügünün temel ölçütlerinden birinin, kaynakların çoğulculuğunda ve bu kaynaklara özgürce ulaşılabilmesinde yattığı söylenebilir. Siyasal sistem ne olursa olsun, bu kaynakların egemen grupların ellerinde çoğalması özgürlüğün çarpitılmasına yol açmaktadır (MacBride, 1993, s. 24).

Rapor, günümüzde enformasyona sahip olma ve önceki dönemlerde hammaddeye sahip olma arasında benzerlik kurmaktadır. Uluslararası iletişimin, yeni iletişim teknolojilerinin etkisinde daha da ilerlediği modern çağda enformasyona sahip olan ülkeler, enformasyonun hem işleyicisi hem de kullanıcısı olma avantajına sahip bulunmaktadırlar. Üçüncü dünya ülkeleriyse iletişim altyapısına sahip olmamaları nedeniyle, kendi enformasyonunu 
üretecek araçlardan yoksun durumdadır. Bu durum üçüncü dünya ülkelerinin gelişmiş ülkelere bağımlılığını artırmaktadır. Raporda üzerinde önemle durulduğu şekliyle, düşünsel ve kültürel plandaki bağımlılığın ekonomik bağımlılık kadar önemli etkilere sahip olduğu da giderek daha çok kabul edilmektedir. Günümüz dünyasında iletişim daha güçlü, daha zengin ve daha iyi donanmışlığın egemenliğinde eşit olmayan taraflar arasında bir değiş tokuş durumuna gelmenin acısını çekmektedir. Bu durum iletişim yapıları ve akımları üzerinde etkili olmakta, sanayileşmiş ülkelerle gelişmekte olan ülkeler arasındaki iletişime dair eşitsizlik ve dengesizliklerin nedenini oluşturmaktadır. Tek yönlü akış olarak özellikle ABD’nin özgür akış olarak kuramsallaştırdığı yaklaşıma karşı çıkılmakta, serbest ve dengeli dolaşımın sağlanması gerektiği ileri sürülmektedir. Akışın yönlendiricisi olan ülkeler, enformasyonu ideolojik bir araç olarak kullanmakta ve tek yönlü akışın gerçekleştiği gelişmekte olan ülkeler üzerinde bir egemenlik kurarak kültürel kimliklerine zarar vermektedir. Bu bağlamda rapor buna engel olunması için, tehdit altındaki kültürü korumak ve güçlendirmek, yerel plandaki iletişimi geliştirmek, büyük medyanın baskılarına karşı bir panzehir işlevi görecek alternatif iletişim biçimleri oluşturmak gerektiğini ileri sürmektedir (MacBride, 1993, s. 34-37).

Haber ajansları anlamında da aşılması zor sorunlar söz konusu olmaktadır. Ulusal haber ajansları gerek habere ulaşma gerekse de haberi geçme noktasında maddi ve teknik imkansızlıklarla uğraşmaktadırlar. Bu durum ulusal haber ajanslarını uluslararası büyük haber ajanslarına bağımlı kılmaktadır. Rapor buna yönelik olarak, ulusal haber ajansı ve diğer iletişim altyapılarından yoksun ülkelerde bunların yaratılmalarını ve mevcut ancak zayıf olanlarının da ıslahını önermektedir (MacBride, 1993, s. 92).

Belirtildiği gibi sanayileşme olgusu, iletişim alanındaki büyük sermaye yatırımlarını daha da artırmıştır. Bu artıştan iki sonuç önem taşımaktadır: 1) Bu girişimin rantabl olması için medyayı kullanan insan sayısı giderek artmalıdır. 2) Büyük kuruluşların denetim ve finansmanları giderek gerekli sermayeye sahip büyük şirketlerin eline geçmektedir (MacBride, 1993, s. 103). Dolayısıyla sanayileşmeyle birlikte iletişim alanı ulus aşırı şirketlerin hakimiyetine geçmekte ve gelişmekte olan ülkeleri de iletişim noktasında bu şirketlere bağlamaktadır. Bu durum belirli şirketlerin iletişim teknolojilerini ellerinde bulundurmalarına ve alanda tekelleşmenin oluşmasına neden olmaktadır. Hamelink, raporun uluslararası iletişim alanında ulus aşırı şirketlerin önemli rolü olduğuna işaret etse de yeni uluslararası enformasyon düzeninin, ulus aşırı şirketlerin düzeni olduğunu fark etmediğini, iddialı olarak bahsedilen "One World" (bir dünya) kavramının ise uluslararası şirketlerin kendi küresel pazarı olabileceğini belirtmektedir (Hamelink'den akt. Mansell \& Nordenstreng, 2006, s. 24).

UNESCO tarafından alınan kararla savunulan ve komisyona verilen görevlerde de önemle vurgulanan yeni iletişim düzeni ve dünya genelinde serbest ve dengeli enformasyon akışına yönelik, ABD başta olmak üzere Batılı merkez ülkelerin tepkileri söz konusu olmuştur. Özellikle Amerika, serbest pazar ve serbest akımı savunarak ticari pazar enformasyonunun modernleşmeye ve kalkınmaya yardım ettiğini belirterek, yeni düzenin hükûmetler tarafından kontrol edilen zorunlu ahlak kuralları koyarak gazetecilerin özgürlüğünü ortadan kaldıracağını ileri sürmüștür (Erdoğan, 1995, s. 254).

NWICO üzerine çalışmalar devam ediyor olsa da proje, 1987'ye kadar çok az bir etkinlikle UNESCO içerisinde kalmayı başarmış ve UNESCO, NWICO'yu 1989 yılında bitirmiştir. Bitirmesinin temelinde, bir yandan Berlin Duvarı'nın yıkılmasıyla başlayan süreç, soğuk savaşın bitmeye yüz tutması ve Bağlantısızlar Hareketi'nin etkisini yitirmesi 
yer almaktadır. Diğer yandan hızla yükselişe geçen neoliberal politikalar da büyük bir etki yaratmıştır (Bulut, 2015, s. 124). 2000’li yıllardan bakıldığında, çevre ülkelerin Bağlantısızlar Hareketi'yle elde ettikleri söz konusu kıpırdanmalar, ortada tartışılabilir bir sorunun olduğu gerçeğinin dışında herhangi bir kazanım sağlamamıştır.

\subsection{Dünya Bilgi Toplumu Zirvesi (WSIS)}

Uluslararası zirveler, politik savunuculuk için değerli kaynakları uygun hale getirme fırsatları sunmaktadır. Dünya zirveleri, BM tarafından çevre, konut ya da gıda gibi küresel meseleleri ele almak üzere düzenlenen bir defalık konferanslardır. Birlikte kararlaştırılmış ilke vizyonlarını geliştirmek ve insanlığın en zor sorunlarından bazılarına olası çözümler geliştirmek için yıllardır birlikte çalışan binlerce politika yapıcıyı içermektedir (Klein, 2004, s. 3). Bu çerçevede WSIS de (World Summit on the Information Society Dünya Bilgi Toplumu Zirvesi) temeline bilgi toplumunu alan bir dünya zirvesi olarak karşımıza çıkmaktadır.

İletişim teknolojilerindeki yenilikle ve kapitalizmin gücünü artırması dolayımında sermayenin gücünü hepten kanıtladığı 1980'ler sonrası dönem, enformasyonun artan önemiyle sermayenin de yönünü enformasyon sahipliğine çevirmesine neden oluşturmuştur. Enformasyonun önem kazandığı ve yarattığı dönüşümle yeni bir toplum biçimi yaratmasıyla oluşan bu durum 'enformasyon toplumu' kavramıyla açıklanmaya bașlanmıştır. Enformasyon toplumu kuramcıları söz konusu paradigma değișimini, teknolojinin belirlediği bir süreç içinde kitlesel üretim ekonomisinden, kitlesel olmaktan çıkmış, ancak teknolojik gelişmelerle kişisel beğenilere uyarlanabilir hale gelmiş kitlesel tüketim ekonomisine geçiş olarak nitelemektedir (Törenli, 2014, s. 84). Enformasyon toplumuna geçişle birlikte üretim ve tüketimin niteliksel dönüşümleri olmakla birlikte, toplumsal ve ülkesel standartlarda zengin-fakir arasındaki farklılıklar bağlamında değişiklikler fazla görülmemekte, aksine var olan farklılık ve eşitsizlikler artmakta ve zenginler zenginliklerini daha büyük noktalara taşımaktadır. Enformasyon toplumu, toplumsal olarak herkesin enformasyona ulaşıyor olması algısını yaratırken, gerçekte var olan gelişmiş ülkelerin ve neoliberal politikalarla daha da etkin hale gelen uluslararası şirketlerin bu enformasyonun sahipliği, işlenmesi ve dağıtımı noktasında gücü ellerinde barındırıyor olmalarıdır. Böyle bir enformasyon toplumu süreci ve anlayışı, WSIS'in temellerini atmıştır.

WSIS süreci, 2000'li yıllarda BM, Uluslararası Telekomünikasyon Birliği (ITU), Dünya Ticaret Örgütü (DTÖ) ve Dünya Bankası (DB) gibi kuruluşların öncülüğünde başlatılan ve dünya çapında devletler ile iletişim alanındaki küresel şirketlerin katılımıyla gerçekleştirilen bir toplantılar dizisidir (Bulut, 2015, s. 131). WSIS, BM'in bir organı olan ITU tarafından ilk olarak 1998'de önerilmiş ve zirve, Birleşmiş Milletler Genel Konseyi tarafından Aralık 2001'de resmen onaylanmıştır. 2002 ve 2003'te dünyanın çeşitli ülkelerinden katılımla bölgesel planlama toplantıları yapılmıştır. Birçok BM zirvesi süreçlerinin aksine, WSIS iki aşamalı olarak planlanmıştır. İlk aşama 10-12 Aralık 2003'te Cenevre'de gerçekleştirilirken, ikinci aşama 16-18 Kasım 2005'te Tunus'ta gerçekleştirilmiştir. Küresel kütüphanelerin, müzelerin ve arşiv topluluklarının görüşleri, zirve amaçları, sorunlar, çözülmemiş konularla ve önümüzdeki yıllarda hükümetlerin, sivil toplum örgütlerinin ve özel sektörün eylem planının uygulanışına bakılarak tartışılmıștır (Berry, 2006, s. 1).

WSIS'in ilk aşaması olan Cenevre aşaması, ilkeler bildirgesi ve eylem planından oluşmaktadır. WSIS'in ilk aşaması temeline herkesin bilgiye erişebileceği, bilgiyi 
üretebileceği ve kullanabileceği bir bilgi toplumunu almaktadır. İlkeler bildirgesinde de belirtildiği şekilde katılımcılar, bunu İnsan Hakları Evrensel Beyannamesi'nde ve Birleşmiş Milletler Sözleşmesi'nde yer alan ilkeler çerçevesinde gerçekleştirmeyi amaçlamaktadırlar (İlkeler Bildirgesi, 2003, s. 1).

Bildirgede, 'Bilgi Toplumu'nun dayanması gereken temel esaslardan biri olarak düşünce ve ifade özgürlüğü kabul edilmektedir. Herkesin bu hakkı kullanabilmesi gerektiği ve bilgi toplumu temelinde iletişimin de önemli bir hak olarak görülmesi ve uygulama alanına sahip olması gerektiği vurgulanmaktadır. Aynı zamanda herkesin her yerde katılımda bulunma firsatına sahip bulunması gerektiği ve hiç kimsenin Bilgi Toplumu'nun sunduğu faydalardan mahrum edilmemesi gerektiği üzerinde durulmaktadır (İlkeler Bildirgesi, 2003, s. 1). Bilgi ve iletişim teknolojilerindeki gelişmeler kutsanmakta ve gelişmişlik düzeyinde etkili olacağı savunulmaktadır. $\mathrm{Bu}$ teknolojilerin tanıdığ imkanların varsayımından hareket edilmekte ancak bunun ne derece imkân sağladığı yönünde veriler sunulmamaktadır. Herkesin bilgiye erişiminden ve bilgi iletişim teknolojilerini kullanmasına vurgu yapılmakla birlikte, 'herkes' kavramı çok açık bir tanım sağlamamaktadır.

Bildirge, ortak bilgi toplumu vizyonundan hareketle, kalkınma hedeflerine erişmek için BiT'lerden faydalanmak gerektiğini, enformasyonun dengesiz akışıyla bağlantılı olacak şekilde de dijital bölünme ve kaynakların eşitsiz dağılımına vurgu yapmaktadır. Bildirge, 'Herkes için Bilgi Toplumu: Temel Prensipler' başlığı altında BİT'lerin sağladığı fırsatlardan herkesin yararlanması önündeki engel ve zorlukları aşmaya yönelik paydaşların rollerine odaklanmaktadır (İlkeler Bildirgesi, 2003, s. 3).

Bildirgenin medyayla ilgili kısmında, bilgi toplumu için esas olan medyanın bağımsızlığı, çoğulculuğu ve çeşitliliğin yanı sıra basın özgürlügü ve bilgi edinme özgürlügü ilkelerine bağlllıklarından söz edilmektedir. İlkesel bağlamda kabul edilmekle birlikte, bahsi geçen bağımsızlık ve özgürlükler uygulamada yer bulamamaktadır. Özellikle 1980'li yıllarda yükselişe geçen neoliberal politikaların, piyasa odaklı toplum kuramı ve serbest piyasayı yüceltip, devlet girişimlerinin azaltılmasına yönelik olması, medyanın özelleşmesini ve beraberinde deregülasyonu getirmiştir. Bu durum, güçlü ulus aşırı şirketlerin medya alanında da tekel haline gelmelerine neden oluşturmuştur. Bilginin akışındaki dengeler de bu ulus aşırı şirketlerin güdümünde bulunmakta, onların çıkarları noktasında bir akış seyri göstermektedir. Bu durum medyadan akan bilginin de ekonomik ve siyasal çıkarlar odağında olduğunu göstermektedir. Çıkar gruplarında yer alan gelişmiş ülkeler gerek bu şirketlerin sahiplik yapılarında yer almalarıyla gerekse de kendi güçlü konumlarıyla medyada temsil alanını kaplamakta, medyadaki enformasyonlara erişim ayrıcalığını da yaşamaktadırlar. Gelişmekte olan ülkeler ise enformasyon akışındaki dengesizlik nedeniyle dezavantajlı kesimler olarak kalmaktadır. Medyadaki nicel artış nitel artışı beraberinde getirmemekte, çok seslilik sağlanamamaktadır.

Bildirgede yer alan ilkeleri somutlaştırmak amacıyla bir 'eylem planı' hazırlanmıştır. Giriş kısmında belirtildiği gibi İlkeler Bildirgesi'nde öngörülen Bilgi Toplumu, devletler ve diğer bütün paydaşlar arasında iş birliği ve dayanışmayla hayata geçirilecektir. Eylem planında yapılması gerekenler üzerinde durulmaktadır, ancak nasıl yapılması ve hangi yöntemlerin kullanılması gerektiğine yönelik fazla açıklayıcı olamamaktadır. Eylem Planı'nda, Sayısal Dayanışma Gündemi yaratılmış ve bu gündem, beșerî, mali ve teknolojik kaynakların amaca yönelik kullanımıyla bütün herkesin yeni ortaya çıkan bilgi toplumuna dahil edilmesini hedeflemiştir. Bu bağlamda ulusal, bölgesel ve uluslararası 
iş birliğine büyük önem atfedilmiştir. Sayısal uçurumun aşılabilmesi için finansman bulunabilmesine yönelik yaklaşım ve mekanizmaların daha etkili kullanılmasına vurgu yapılarak, yeni yaklaşım ve mekanizmaların araştırılması gerektiği belirtilmektedir (Eylem Planı, 2003, s. 1-12).

Berry'nin (2006, s. 4) belirttiği gibi, bildirge ve eylem planının onaylanmasına rağmen, birinci aşamada çözülemeyen en tartışmalı konu internet yönetişimi olmuştur. Hükümet yetkilileri, özel sektör sözcüleri ve sivil toplum temsilcileri, internetin daha şeffaf yönetimini teşvik etmek için alınan tedbirlere, altyapı ve hizmetleri genişletmeye yönelik geliştirilmiş politika ve medyada açık diyaloğu ve tartışmayı destekleyen davranış kurallarına destek aramaya başlamışlardır, ancak WSIS'i takiben, sürecin ve sonuçlarının ekonomik açıdan dezavantajlı kişilerin karşılaştığı sorunları çözmek ve eyleme geçmek için yenilenmiş bir temel sağlamayı başardığı konusunda tartışmalar da devam etmektedir (Mansell \& Nordenstreng, 2006, s. 26). Tartışmalara temel oluşturduğu şekilde mevcut siyasi ve ekonomik yapılar bilgiye ve internet üzerindeki enformasyona erişim konusundaki dengesizlik ve eşitsizlikleri çözme noktasında kendi içinde çelişkilerini taşımaktadır. Böylelikle WSIS'in birinci aşamasında ele alınan medya özgürlüğü, iletişim hakkı gibi konular da avantajlı kesimlerin kullanabilirliğini yaratmakta ve dezavantajlı kesimler olarak gelişmekte olan ülkelerin geri planda kalmasına neden olmaktadır.

WSIS'in Tunus'ta gerçekleşen ikinci aşaması, Tunus Taahhüdü ve Tunus Gündemi'nden oluşmaktadır. Tunus Taahhüdü'nde ve Bilgi Toplumu için Tunus Gündemi'nde Cenevre'deki İlkeler Bildirgesi ve Eylem Planı'ndaki konular ele alınmakta ve kabul edilmektedir. Plandaki maddelerin eyleme geçirilmesine yönelik hükümetlere, özel sektöre, sivil toplum kuruluşlarına ve uluslararası örgütlere seslenilmektedir. BİT’lerin yaygınlaştırılmasına büyük önem atfedilmekte ve BİT’lerin yaygınlaştırılmasıyla enformasyondaki akışın, enformasyona erişimin dengesizlik ve eşitsizliklerinin çözüleceğine, yoksulluğun azalacağına yönelik inançlar söz konusudur (Bilgi Toplumu İçin Tunus Gündemi, 2005). BM'nin yaptırımsız iyi niyet çağrıları aynı NWICO'da (MacBride Raporu'nda) olduğu gibi WSIS'te de sözde kalmış ve sonuca ulaşamamıştır. Bugün gelinen nokta itibarı ile 80'lerin sonunda NWICO'yu bitiren BM, WSIS'in çlktılarının takibini de bırakmıştır. Özetle her ne kadar iyi niyetli uluslararası girişimler olmuş olsa da kapitalist sistem ve buna bağlı olarak merkez ülkelerin isteksizlikleri, söz konusu tüm girişimlerin sonuçsuz kalmasına neden olmuştur.

\section{Sonuç ve Öneriler}

Küreselleşmeyle birlikte gelişme gösteren iletişimin uluslararasılaşması, enformasyonun uluslararası akışında yaşanan dengesizlikleri de beraberinde getirmiştir. Geçmişteki istilaya dayalı toprak sömürgeciliğinin yerini enformasyonun kontrolüne dayanan dijital sömürgecilik biçimleri almıştır. Ekonomik ve siyasal güce sahip olan ülkelerin enformasyon sahipliğini de ellerinde bulundurmaları, var olan güçlerini arttırmalarına ve egemenlik yapılarını sağlamlaştırmalarına temel oluşturmaktadır. Bununla birlikte gelişmekte olan ülkelerin bu ülkelere ekonomik ve siyasal bağlılıkları yanında enformasyon açısından da bağlılıkları söz konusu olmaktadır. Enformasyon akışının tek yönlü olduğu bu sistem tepkiler çekmiş ve uluslararası arenada çözüm arayışlarına gidilmesine neden olmuştur. Bilgi iletişim teknolojilerinin gelişmesiyle yaratılmak istenen bilgi toplumu da var olan tek yönlülüğü ve eşitsizliği yok etmeyi amaçlamakla birlikte başaramamıştır. Bu bağlamda gerçekleșen uluslararası yaklașımlar, ekonomik temel ilişkileri de ele alındığında NIEO, NWICO, MacBride Raporu ve WSIS'tir. 
NWICO ve WSIS'in değindiği temel konulara bakıldığında, her ikisinin de iletişim konusundaki hak ve özgürlükler isteminin paralel olduğunu söylemek mümkündür. WSIS'in, bilgi toplumunda herkesin enformasyona eşit erişim, ulaşım ve kullanabilmesi talebiyle, MacBride Raporu'nda (NWICO) yer alan enformasyon akışındaki dengesizlik ve eşitsizliklerin aşılmasına yönelik istemleri benzerlik göstermektedir. Her iki oluşum arasında çeyrek asırdan fazla bir süre geçmiş olmasına karşın, MacBride raporundaki taleplerin WSIS'te tekrar karşımıza çıkmış olması, NWICO'nun çevre ülkeler adına bir kazanım sağlamadığının açık bir göstergesi olduğunu söylemek mümkündür. MacBride Raporu; NIEO ve NWICO'nun gerçekleşmesiyle ortaya çıkacak olan yeni ekonomik ve iletişim düzeniyle birlikte, gelişmekte olan ülkelerin teknolojik altyapılarını sağlayarak iletişim alanında ilerleme göstereceği ve enformasyon akışındaki dengesizliklerin de bu şekilde çözülebileceğini savunmaktadır. WSIS'te ise BİT'lerin gelişmesiyle herkesin enformasyona eşit ve adil şekilde erişebileceği düşüncesinin yanı sıra yoksullukların azalmasının da BíT’lerin geliştirilmesi ve yaygınlaștırılmasıyla mümkün olduğu görüşü ileri sürülmektedir.

MacBride Raporu'nda (NWICO) iletişim altyapısı ve bilgi akıșı konularında finanse etme görevi devletlere/hükumetlere yüklenirken, WSIS'te hükumetlerin yanı sıra özel sektör, sivil toplum kuruluşları ve uluslararası örgütler de bu işte görevlendirilmektedir. $\mathrm{Bu}$ durum, liberal dünya düzeninde devletin iletişim sektöründen çekildiğinin ya da bu sektördeki etkinliğini kaybettiğinin de bir kanıtı durumundadır. Aynı zamanda WSIS, MacBride Raporu'ndan farklı olarak, dijital bölünme sorununu da odağına alarak enformasyon akışındaki dengesizlik konusuyla ilişkilendirmiştir.

MacBride Raporu, dönem itibariyle ulus aşırı şirketlerin egemenliği ve tekelleşme noktasına da değinmekte ve bunları azaltmaya yönelik çabaları teşvik etmektedir. Ancak günümüzdeki iletişim alanındaki sahiplik yapıları ve WSIS'te ulus aşırı şirketlerin etkinliği MacBride Raporu'nun aksine gelişmelerin yaşandığının kanıtı durumundadır. MacBride Raporu, gelişmekte olan ülkelerin talebi ve UNESCO'nun desteğiyle varlık kazanırken, WSIS doğrudan farklı grupların sorunsal bağlamda eklenmesiyle gerçekleştirilmiştir. Hükümetler, özel sektör, sivil toplum kuruluşları ve uluslararası örgütler önemli aktörler olarak karşımıza çıkmaktadır. $\mathrm{Bu}$ anlamda çalışmamızdaki araştırma sorularından hareketle, uluslararası enformasyon akışındaki tek yönlülüğün ülkeler/uluslar düzeyinden çok uluslu şirketler düzeyine geçtiği ve onların çıkarları doğrultusunda yönlendiği açıkça görülmektedir.

Sonuç olarak, uluslararası arenada değişen ekonomik, sosyokültürel ve politik süreçler, ülkeler arasındaki iletişim düzeni ve sistemlerini de etkilemektedir. Var olan eşitsizlik yapıları her dönemde farklı iktidar gruplarının lehine gelişmektedir. 20. yy. da kapitalist sistemin ilerlemesini daha net şekilde göstermesiyle, sermaye sınıfları egemen odağı olmakta ve iletişim sisteminin de yönlendiricisi konumuna gelmektedir. Batının demokratik süreçlerle bağlantılı eşitlik anlayışı, iletişim alanında başat rolü alan enformasyon akışındaki mevcut eşitsiz ve dengesizliklere yönelik sözde çabaları meydana getirmiştir. Bu çabaların raporları olarak incelediğimiz MacBride ve WSIS, alınan kararların, yapılmak istenenlerin, 'iyi niyet' düzeyinin çok da ötesine geçemediği görülmüştür.

ITU'nun web sitesinde, Bilgi Toplumu Dünya Zirvesi Formu'nun (WSIS), 2017'nin değişen bilgi ve bilgi topluluklarını göz önüne alarak ortaya çıkan eğilimleri belirlemek ve 
ortaklıkları geliştirmek için bilgi değişimi, bilgi yaratımı ve en iyi uygulamaların paylaşımı için bir fırsat sunduğu belirtilmektedir. Zirve bağlamında, sürdürülebilir kalkınma hedefleri ve uygulamaları için BİT’lerin rolünün tartışılacağı ve 2030 sürdürülebilir kalkınma gündeminin takibi ve gözden geçirilmesi için küresel mekanizmaların dikkate alınacağı belirtilmektedir. Forum; ITU, UNESCO, UNDP ve UNCTAD tarafından ve diğer BM kuruluşlarıyla yakın iş birliği içinde organize edilmiştir (www.itu.int, 2017). Bu açıdan bakıldığında bile belli çıkarlara odaklanmış grupların güdümünde bir forum olduğu görülmektedir. Enformasyon toplumu ve enformasyonun akışıyla ilgili gerçekleştirilen çabaların yeterince başarıya ulaşmamasının temelinde belirli çıkarların önceliği bulunmaktadır. Özellikle kapitalizmin ve piyasa odaklı grupların, piyasanın başat aktörü şirketlerin öne çıkması ve bu girişimlerde başı çekmeleri, görünürde bir çaba ortaya koymakta ancak uygulamada geçerlilik göstermemektedir.

Enformasyon dengesizliğinin giderilmesi ve dünya bilgi toplumunun oluşturulabilmesi için enformasyon dengesizliği üzerine merkez ülkelerden bağımsız kurumlar oluşturularak bu kurumların uluslararası iş birliği içinde olması; söz konusu uluslararası girişimlerin yılda iki kez toplanarak faaliyet raporlarını şeffaf bir şekilde ilgili BM organlarına sunmaları; belirlenecek bir miktarda abone sayısına ulaşan uluslararası haber ajanslarının ürettikleri haberlerin en az \%15'i kadarının, çevre ülkelere bedelsiz olarak sağlamasının zorunlu tutulması; söz konusu bilgi toplumuna ulaşmada ihtiyaç duyulan ekonomik ve teknolojik gereksinimlerin tamamının, merkez ülkeler, çok uluslu şirketler (BİT şirketleri ve Medya kuruluşları) ve sivil toplum kuruluşlarınca bir plan dahilinde düzenli hibe ve bağışlar yoluyla giderilmesinin ulusal ve uluslararası hukuk kurallarıyla zorunlu tutulması ve çevre ülkelerin söz konusu hibe ve bağıș politikalarından faydalanabilmesi için, bilgi toplumuna geçiş süreci çerçevesinde kısa, orta ve uzun vadeli kalkınma planlarını oluşturarak ilgili BM organları tarafından denetimi kabul etmelerinin sorunun çözümü açısından bir başlangıç noktası oluşturabileceği düşünülmektedir.

\section{Kaynakça}

Akdemir, S. (2002). Enformsyon egemenliği. Kurgu Dergisi(19), 239-255.

Altay, D. (2005). McLuhan. N. Rigel, G. Batuş, G. Yücedoğan, \& B. Çoban (Dü) içinde, Kadife karanlık: 21 yüzyıl iletişim çağını aydınlatan kuramcılar (s. 9-74). İstanbul: Su Yayınevi.

Ansah, P. (1991). Uluslararası iletişimde haklar ve değerler mücadelesi. Y. Kaplan (Dü.) içinde, Enformasyon devrimi efsanesi (Y. Kaplan, Çev., s. 199-231). Kayseri: Rey Yayınları.

Başaran, F. (2004). Enformasyon toplumu politikaları ve gelişmekte olan ülkeler. İletişim Araştırmaları Dergisi, 2(2), 7-31.

Berry, J. W. (2006). The World Summit on The Information Society (WSIS): A global challenge in the new millennium. International Journal of Libraries and Information Studies, 56(1), 1-15.

Bilgi toplumu için tunus gündemi. (2005). 12 19, 2020 tarihinde www.itu.int: https:// www.itu.int/net/wsis/docs2/tunis/off/6rev1.pdf adresinden alındı

Bulut, Ç. (2015). NWICO'dan WSIS'e: Uluslararası iletişimde dönüşüm ve mücadele. Gazi Üniversitesi İletişim Kuram ve Araştırma Dergisi, 41, 119-138. 
Calsson, U. (2003). The rise and fall of NWICO: From a vision of international regulation to a reality of multilevel governance. Nordicom Review, 24(2), 31-67.

Değirmen, G., Akıncı, Z., \& Özbükerci, İ. (2016). Bilgi toplumu ve dijital uçurum. İnönü Üniversitesi iletişim Fakültesi Elektronik Dergisi, 2(1), 102-118.

Erdoğan, İ. (1995). Dünyanın çarpık düzeni uluslararası iletişim. İstanbul: Kaynak Yayınları.

Eylem Planı. (2003). 12 13, 2020 tarihinde www.itu.int: https://www.itu.int/dms_pub/ itu-s/md/03/wsis/doc/S03-WSIS-DOC-0005!!PDF-E.pdf adresinden alındı

Geray, H. (2003). İletişim ve teknoloji: uluslararası birikim düzeninde yeni medya politikaları. Ankara: Ütopya Yayınevi.

Gürkan, Ö. (2001). Küreselleşme ve yeni uluslararası ekonomik düzen. Sosyal ve Beșeri Bilimler Araştırmaları Dergisi(3), 1-15.

Güzelsarı, S. (2012). Küreselleşme. G. Atılgan, \& E. Aytekin (Dü) içinde, Siyaset Bilimi: Kavramlar, ideolojiler, disiplinlerarası ilişkiler (s. 235-249). İstanbul: Yordam Yayınevi.

Hamelink, C. (1991a). Enformasyon devriminden sonra yaşam sürecek mi? Y. Kaplan (Dü.) içinde, Enformasyon Devrimi Efsanesi (Y. Kaplan, Çev., s. 11-32). Kayseri: Rey Yayınları.

Hamelink, C. (1991b). Merkez ve çevre ülkeler arasındaki enformasyon dengesizliği. Y. Kaplan (Dü.) içinde, Enformasyon Devrimi Efsanesi (Y. Kaplan, Çev., s. 257-277). Kayseri: Rey Yayınları.

Illkeler Bildirgesi. (2003). 12 15, 2020 tarihinde www.itu.int: https://www.itu.int/dms_ pub/itu-s/md/03/wsis/doc/S03-WSIS-DOC-0004!!PDF-E.pdf adresinden alındı

Klein, H. (2004). Understanding WSIS: An Institutional Analysis of the UN World Summit on the Information Society. Information Technologies \& International Development Journal, 1(3-4), 3-12.

MacBride, S. (1993). Bir çok ses, tek bir dünya: iletişim ve toplum-bugün ve yarın. Unesco. Ankara: Unesco Türkiye Milli Komisyonu Yayınları.

Mansell, R., \& Nordenstreng, K. (2006). Great media and communication debates: WSIS and the MacBride Report. Information Technologies \& International Development Journal, 3(4), 15-36.

Mattelart, A., \& Mattelart, M. (2016). İletişim kuramları tarihi. İstanbul: İletişim Yayınları.

McPhail, T. (1991a). Yanlış bir başlangıç. Y. Kaplan (Dü.) içinde, Enformasyon Devrimi Efsanesi (Y. Kaplan, Çev., s. 165-197). Kayseri: Rey Yayınları.

McPhail, T. (1991b). Yeni uluslararası enformasyon ve iletişim düzeni. Y. Kaplan (Dü.) içinde, Enformasyon Devrimi Efsanesi (Y. Kaplan, Çev., s. 141- 164). Kayseri: Rey Yayınları.

Mohammadi, A. (1991). Kültür emperyalizmi ve kimlik sorunu. Y. Kaplan (Dü.) içinde, Enformasyon Devrimi Efsanesi (Y. Kaplan, Çev., s. 141-164). Kayseri: Rey Yayınları.

Nordenstreng, K. (2010). 112020 tarihinde https://sites.tuni.fi/ uploads/2019/12/3005939b-grenoble.pdf adresinden alındı 
Seyidoğlu, H. (1980). Yeni uluslararası ekonomik düzen ve az gelişmiş ülkeler. Atatürk Üniversitesi Íktisadi ve İdari Bilimler Dergisi, 4(3-4), 263-300.

Törenli, N. (2014). Kriz çözücü siyaset geç kapitalizm evresinde 'tekno-siyasal paradigma' kavramlaştırması üzerinden siyaset ve kriz ilişkisine bakış. Mülkiye Dergisi(35), 75-100. https://dergipark.org.tr/tr/pub/mulkiye/issue/271/665 adresinden alındı

Uğur, A. (1991). Zihinlerin yeni efendileri medyalar. Y. Kaplan (Dü.) içinde, Enformasyon Devrimi Efsanesi (Y. Kaplan, Çev., s. 233-256). Kayseri: Rey Yayınları.

Uluç, G. (2003). Küreselleşen medya: iktidar ve mücadele alanı. İstanbul: Anahtar Kitaplar.

Van Audenhove, L., Burgelman, J., Nulens, G., \& Cammaerts, B. (1999). Information society policy in the developing world: a critical assessment. third world quarterly, 387-404. Mart 15, 2021 tarihinde http://www.jstor.org/stable/3992923 adresinden alındı

Walcott, H. F. (1994). Transforming qualitative data: description, analysis and Interpretation. London: Sage Publications.

www.itu.int. (2017). Ocak 24, 2021 tarihinde www.itu.int: www.itu.int/net4/wsis/ forum/2017/ adresinden alındı

Yeldan, E. (2008). Küreselleşme, kim için? İstanbul: Yordam Yayınevi. 


\section{Information Imbalance in The Historical Process, International Initiatives and Solution Proposals}

Ahmet Öztekin (Asst. Prof. Dr.)

Pınar Ayhan (Ph.D. Student)

\section{Extended Abstract}

One of the most frequently discussed topics during the transition to the Information Society has been the concepts of information imbalance and information flow. As a result of the surrounding countries' awareness, a number of international initiatives with demands for a balanced flow of information have been implemented in the 1970s. Different international meetings have been held in different bodies of the United Nations at the request of the surrounding countries, where discussions on the solution to the problem have been discussed. The demands for a "New International Economic Order" that emerged as a result of the "New World Information and Communication Order" prepared as a result of the initiative of the "Many voices, One world," as the MacBride report in question is titled, are formal, even if a solution to the problem is not expected at this time. Following the continuation of the problem, the issues have been discussed again with the World Information Society Summit, which had been held in two separate sessions under the auspices of the United Nations in 2003 and 2005, but unfortunately, no concrete steps have been taken.

The above-mentioned international initiatives on information imbalance have been discussed in this study. This study aims to address the imbalance within the framework of international initiatives by providing information, both in the processes of international initiatives discussed the problem with a holistic structure for the last 16 years since the last attempt to handle the developments in solution the problem by taking the point seeks to offer some suggestions.

The study, are international initiatives aimed at resolving the imbalance in information flow successful? And with the capitalist perspective, why the problems moved from countries/nations level to multinational companies level has been built on questions. The scope of this study, which was prepared to understand and explain the international community's approach to the problem in question and the mechanisms created within the framework of solving the problem, is the efforts to eliminate this imbalance rather than the information imbalance in the context of the unbalanced flow of information. The international initiatives undertaken in this context are the study's limitation. The study method has been qualitative descriptive analysis in order to better understand the aforementioned initiatives and to explain the processes more clearly.

The disparity in the rates of progress of countries throughout history has accelerated with globalization and has continued to grow in the economic, political, and cultural spheres. One of these growing imbalances is the imbalance in information flow. Globalization and digitalization, as well as the rapid widening of the gap between the central and surrounding countries, have exacerbated the already precarious situation in the flow of information. At this point, the digital revolution is a significant multiplier in the growing information imbalance. 
One of the most commonly used expressions to describe today's societies is "information society." After the industrial society, information, which is a notification and information process in its most basic form, is the cornerstone of the social structure. The transition from industrial to information society has resulted in significant changes in the structure and form of social production. Production in an industrial society is carried out by machines, whereas production in an information society structure is carried out by technologies and information networks that enable the development of these technologies. The state of development of the country is evaluated on the scale of industrialization in the old structure of society, whereas the information owned together with the new structure of society is evaluated by the use of existing technological infrastructure for the production of new information and the processing of information. In this sense, countries/nations can be divided into two categories: those who can and cannot access information. Contrary to claims that the information revolution will reduce the gap between international levels of development, it is observed that the gap between both categories is gradually widening.

Based on discussions of the New International Economic Order, the New World Order of Information and Communication (NWICO) is a communication-related derivative of parallel requests (NIEO). In fact, at many points, it is also possible to assert that the NIEO demands, and the outputs sought by these demands are inextricably linked to NWICO. This is stated unequivocally in the MacBride report, which has been released following the NWICO initiative.

Following NWICO, the United Nations held two international world summits on the issue of information imbalance. World summits are one-time conferences held by the United Nations to address global issues such as the environment, housing, and food. It consists of thousands of policymakers who have collaborated for years to develop their vision of mutually agreed-upon principles and possible solutions to some of humanity's most difficult problems (Klein, 2004, s. 3). In this context, WSIS is also the most recent international summit held in 2003 and 2005 to address the problem as a World Summit based on the information society.

As a result of the study, it was determined that the imbalance was transferred from the countries/nations level to the level of multinational companies and it was found that the unbalanced flow is still occuring. In light of these results, several concrete solution ideas to solve the problem have been included.

Keywords: International Communication, Information Imbalance, NIEO, NWICO, MacBride Report, WSIS.

Bu makale intihal tespit yazılımlarıyla taranmıştır. Intihal tespit edilmemiştir.

This article has been scanned by plagiarism detection softwares. No plagiarism detected.

Bu çalışmada "Yükseköğretim Kurumları Bilimsel Araştırma ve Yayın Etiği Yönergesi” kapsamında uyulması belirtilen kurallara uyulmuştur.

In this study, the rules stated in the "Higher Education Institutions Scientific Research and Publication Ethics Directive" were followed.

Yazarların çalışmadaki katkı oranları eşittir.

The authors' contribution rates in the study are equal.

Çalışma kapsamında herhangi bir kurum veya kişi ile çıkar çatışması bulunmamaktadır.

There is no conflict of interest with any institution or person within the scope of the study. 